Article

\title{
An Eco-Critical Analysis of Climate Change and the Unthinkable in Amitav Ghosh's Fiction and Non-Fiction
}

\section{Suhasini Vincent}

Department of English, Université Paris 2_Panthéon Assas, 75006 Paris, France; suhasini.vincent@orange.fr

Received: 26 April 2018; Accepted: 5 June 2018; Published: 7 June 2018

\begin{abstract}
In his work of non-fiction The Great Derangement (2016), Amitav Ghosh examines the inability of the present generation to grasp the scale of climate change in the spheres of Literature, History and Politics. The central premise in this work of non-fiction is based on the statement that literature will one day be accused of its complicity with the great derangement and of blind acceptance of the climate crisis. This paper will study how Ghosh's fictional and non-fictional enterprise voices a call for more imaginative and cultural forms of fiction that articulate resistance against materialism that can destroy our planet. We shall see how Ghosh's fictional enterprise falls within the sphere of postcolonial eco-criticism that considers the phenomenon of "material eco-criticism". I shall also reveal Ghosh's environmental advocacy in his works of fiction, The Ibis Trilogy and The Hungry Tide. This paper will analyze how the Ibis Trilogy is not just an exploration of the particularly heinous operation of imperial power leading up to the Opium Wars but is also an eco-critical narrative that articulates resistance against the violence of climate change. A study of The Hungry Tide will also reveal how this hybrid literary text is both a historical account of the Marichjhapi massacre and a plea to preserve the eco-system of our time. I shall thus consider the challenges that climate change poses for the postcolonial writer and the evolving grid of literary forms that shape the narrative imagination.
\end{abstract}

Keywords: advocacy; biodiversity; eco-criticism; ecology; eco-materialism; eco-narrative; postcolonialism; sustainability

\section{Introduction ${ }^{1}$}

In his fiction and non-fiction, Ghosh explores the problems of conserving biodiversity, distrusts materialistic forces that plunder the planet's natural resources, and takes part in the new emerging paradigm of making a material turn, thus considering possible ways to analyze language and reality, human and nonhuman life, mind and matter, without falling into dichotomous patterns of thinking. I shall thus consider the challenges that climate change poses for the contemporary postcolonial writer and the evolving grid of literary forms and conventions that have surfaced to shape the narrative imagination. I intend to explore how Ghosh's eco-narrative is an imaginative form of fiction that portrays what Graham Huggan and Helen Tiffin describe as "greening postcolonialism" in Postcolonial Eco-Criticism, whereby he offers a new perspective of concerns and debates that affect the world at

1 Amitav Ghosh is a contemporary Indian diasporic writer who resides in New York and teaches at Colombia University. He was the recipient of the Crossword Book Prize for The Hungry Tide in 2004. In 2007, he was awarded the prestigious Padma Shri award by the Indian President, one of India's highest honors for his contribution to Indian literature. As a Franco-Indian researcher in the Université Paris 2-Panthéon Assas where I teach Legal English, my research focusses on the legal scope of environmental laws in postcolonial countries and explores eco-critical activism in the fiction and non-fiction of Ghosh. 
large and the way these issues can be highlighted through eco-narrative versus eco-tourism, eco-critical activism, environmental advocacy and aesthetics (Huggan and Tiffin 2010, p. 12). We shall see how Ghosh's fictional enterprise falls within the sphere of postcolonial eco-criticism that explores the problems of conserving biodiversity, distrusts the grandeur of empty statements and hypocritical rhetoric in the name of Free Trade, and highlights how postcolonial literature is rich in discursive formulations and the stories of narrative matter replete with their material mesh of meanings that can serve as signifying forces. Material eco-criticism considers how "the world's material phenomena are knots in a vast network of agencies, which can be "read" and interpreted as forming narratives, stories. Developing in bodily forms and in discursive formulations the stories of matter is a material "mesh" of meanings, properties, and processes, in which human and nonhuman players are interlocked in networks that produce undeniable signifying forces" (Iovino 2014, pp. 1-2). We shall see how Ghosh reconfigures new spaces of postcolonial identity by rightfully claiming identity through an eco-narrative. His fiction enables the reader to identify himself with the central premise of articulating resistance against the colonialist materialistic forces of a global imperium.

\section{Challenges that Face the Postcolonial Writer}

\subsection{Complicity with the Great Derangement}

In The Great Derangement: Climate Change and the Unthinkable, Ghosh wonders if the present generation is deranged. He probes into the reasons for the postcolonial writer's imaginative failure in the face of global warming. In his fiction, Ghosh has examined the inability of the present generation to grasp the scale and violence of climate change and posits that this is reflected in the literature of our time, in the recording of history and in the political ambience of our day. Ghosh posits that the extreme nature of today's climate changes has resulted in making writers immune and resistant to contemporary modes of thinking and imagination. In the chapter entitled "Stories" in The Great Derangement, Ghosh asserts that certain phenomena such as hundred-year storms and freakish tornados do not figure in serious literary fiction but get relegated to other genres such as science fiction or fantasy. Ghosh delves into the tangled web of the carbon economy with its contradictory and counterintuitive elements. He suggests that politics has suffered the same fate as literature and has become a matter of personal moral reckoning rather than an arena of collective action. He further argues that to limit fiction and politics to individual moral adventure comes at a great cost. In the following sections of this paper, I intend to detail how in the face of natural hazards and vagaries of weather, Ghosh through his eco-critical fiction has shown how fiction is the best of all cultural forms to confront the most urgent task of our time of moving the issue of climate change out of narrow corridors of meteorological science into the wider precincts of culture, politics and power. Through his eco-critical sleight of hand, Ghosh reveals how climate change is the result of a set of interrelated histories that promoted and sustained our collective dependence on fossil fuels, and that it is a kind of derangement to say we want a different world but act in a way that ensures the continuance of the present one.

\subsection{Climate Change and Displacement of Ecological Refugees}

Ghosh recalls childhood family accounts of his ancestors who had been ecological refugees displaced from their roots on the banks of the Padma River in the mid-1850s when the mighty river on a whim decided to change course. In The Great Derangement: Climate Change and the Unthinkable, he relates how the few vagrant inhabitants traversed forests and dry land moving westward to settle once again on the banks of another civilization-housing river, the Ganges. Ghosh warns us that the river, a stable presence in the lives of his forefathers, had transformed into a meandering force that could not be relied on, nor taken for granted in the same way as the air we breathe. Similarly, in The Hungry Tide, Ghosh writes of the fickle nature of the landscape where mangrove forests of the Sundarbans appear and disappear, merge and submerge, surprise and disrupt human lifestyles. Ghosh muses, "Even a child will begin a story about his grandmother with the words: 'in those days the river wasn't here, 
and the village was not where it is ... '" (Ghosh 2016, p. 6). He continues with the account of how the air we breathe can also come to life with sudden and deadly violence as in the Congo in 1980 when a great mass of carbon dioxide from Lake Nyos descended into the neighboring valleys and resulted in deaths of men and livestock that could be attributed to asphyxia. He draws on his experiences in the metropolises of Delhi and Beijing to show how our use of energy in lighting, transport and production results in its all-encompassing presence inflaming lungs and sinuses. Ghosh wonders if contemporary writers are blind to potentially life-changing hazards and threats and if they consider what climate change signifies for the future. "But why? Are the currents of global warming too wild to be navigated in the accustomed barques of narration? But the truth, as it is now widely acknowledged, is that we have entered a time when the wild has become a norm: if certain literary forms are unable to negotiate these torrents, then they will have failed-and their failure will have to be counted as an aspect of the broader imaginative and cultural failure that lies at the heart of the climate crisis" (Ghosh 2016, p. 8). Ghosh also comments on how writers such as Arundhati Roy and Paul Kingsnorth have chosen to voice their thoughts on climate crisis through non-fiction instead of in prose. He attributes this preference to the resistance that climate change presents to what is now regarded as serious fiction. In the ensuing sections of this paper, we shall see why Ghosh considers globalization, empire and the bourgeois novel as closely linked to the history of climate crisis that faces contemporary society.

\subsection{Materialistic Colonial Intent in the Name of Free Trade}

In the Ibis Trilogy-The Sea of Poppies (Ghosh 2008), The River of Smoke (Ghosh 2011) and Flood of Fire (Ghosh 2012) - Ghosh's fictional space reveals how in India, the sap of the opium poppy, papaver somniferum linnaeus which is both a palliative and a poison, has long been produced since Mughal times. However, it was during the mid-nineteenth century that the British imposed their trade in Indian opium upon China through the two Opium Wars (183-42 and 1856-60), thus not only monopolizing the delivery of the narcotic to the European market, but also changing the course of economic and political relations between the East and the West. The West's fascination for the East as seen in the Orientalist initial quest for spices such as nutmeg, cloves, pepper, coffee, cacao, sugar and tea led eventually to the discovery of the addictive narcotic drug "opium". Ghosh's fictional enterprise of reliving the colonial period is typical of what Ashcroft, Griffiths and Tiffin claim to be "the rereading and the rewriting of the European historical and fictional record" (that) "is a vital and inescapable task at the heart of the postcolonial enterprise" (Ashcroft et al. 2002, pp. 196). It is interesting to make a reference to Opium: Uncovering the Politics of the Poppy, where Pierre-Arnaud Chouvy explains how a triangular trade developed between Britain, India and China in which "Indian opium provided the silver required to buy tea legally from China for shipments to London" (Chouvy 2010, p. 5). Similarly, in Opium, Empire and the Global Political Economy, Carl Trocki posits that "the British Empire, the opium trade, and the rise of global capitalism all occurred together" (Trocki 1999, p. 7) and this statement is true in River of Smoke where Ghosh's second volume of the Ibis Trilogy reveals how "gold and silver from the West crossed the Atlantic or the Pacific, it ultimately found its way to Asia (east of Suez) to purchase the "riches of the East" and to allow the otherwise deprived inhabitants of the northwest Eurasian peninsula to share in the fabled Oriental splendors" (Trocki 1999, p. 8). The postcolonial enterprise in countering what Edward Said describes in Orientalism as "the ineradicable distinction between Western superiority and Oriental inferiority" (Said 1998, p. 42) is evident in Ghosh's postcolonial textual response in Sea of Poppies where the margins write back and lay bare materialistic colonial intent of the past by reconfiguring and reliving the opium trade in the fictional space. The various exchanges with the Chinese authorities and the colonial traders reveal, on the one hand, the resistance mounted by the former to stamp out the opium trade, and on the other hand, the cynical pursuit of self-interest by the British merchants whose opium-laden ships thrive on vast profits from drug trafficking. In River of Smoke, Ghosh describes the plight of sailors in ships carrying opium by tracing the journey of the sticky, addictive, canon-sized opium clay balls or "foreign mud" from the wharves of the silty Hoogly River to the port city of Canton on the Pearl River. The exorbitant price of the drug leaves families 
in a state of debt. As an impediment to business and a breaker of family life, the opium trade in the fictional space of the Ibis Trilogy is cast with a cloak of death as it destroys families and family life.

The various interactions with colonial and elite native powers reveal how feudal India transformed into the zamindari system of ownership where tax collectors or zamindars became landowners to the detriment of powerless peasants. In Sea of Poppies, Deeti and her farming community are thus forced to cultivate poppy by the Ghazapore trading factory, a colonial monopoly.

"Back then, a few clumps of poppy were enough to provide for a household's needs, leaving a little over, to be sold: no one was inclined to plant more because of all the work it took to grow poppies, fifteen ploughings ... Come the cold weather, the English sahibs would allow little else to be planted; their agents would go from home to home, forcing cash advances on the farmers, making the sign asami contracts. It was impossible to say no to them: if you refused they would leave their silver hidden in your house, or throw it through a window. It was of no use telling the white magistrate that you had not accepted the money and your thumbprint was forged: he earned commissions on the opium and would never let you off. And, at the end of it, your earnings would come to no more than three-an-a half sicca rupees, just about enough to pay off your advance." (Ghosh 2008, pp. 30-31)

Before the growth of the opium trade in the 1830s, opium was grown for home consumption with poppies being allowed to sprout in small clusters between winter crops such as wheat masoor dal and vegetables for use in " . . a dish of stale alu-posth, potatoes cooked in poppy-seed paste ... or massaging hair with poppy-seed oil, ... to be used during illnesses, or at harvests and weddings" (Ghosh 2008, pp. 7-30). As harvesting opium from poppy capsules entailed fifteen ploughing sessions, four periods of expert lancing lasting for a three-week period, drying capsules for weeks, picking, spreading and thrashing to obtain the seed crop, in earlier times, the country peasants grew the crop for personal use and not for trade. As opium slowly became the medium of exchange in trade relations, the colonial sahibs or masters imposed forced poppy cultivation and made the farmers sign contracts. Faced with the inevitable situation of cultivating the crop at a loss or facing a trial where the magistrate earned commissions from the same opium, poor peasants such as Deeti in the fictional space must face the consequences of revolving debt. The increasing production of opium in the 19th century colonial economy also resulted in the coolies or workers becoming "habitual opium-eaters, who sat always as if in a dream, staring at the sky with dull, dead eyes" (Ghosh 2008, p. 35). The opium seems to hold sway even over the insects who buzz around the sap. Coolies such as Deeti's husband Hukam Singh resort to opium to dull their pain. The monkeys in the opium factory also swing placidly under the influence of the fumes. The reader has a glimpse of the inhuman conditions of the workers in the Ghazipur Sudder Opium factory or Ghazeepore Carcanna through Deeti's visit.

"The air inside was hot and fetid, like that of a closed kitchen, except that the smell was not of spices and oil, but of liquid opium, mixed with the dull stench of sweat-a reek so powerful that she had to pinch her nose to keep herself from gagging. No sooner had she steadied herself, than her eyes were met by a startling sight-a host of dark, legless torsos were circling around and around, like some enslaved tribe of demons ... When her eyes had grown more accustomed to the gloom, she discovered the secret of those circling torsos: they were bare-bodied men, sunk waist-deep in tanks of opium, tramping round and round to soften the sludge. Their eyes were vacant, glazed, and yet somehow they managed to keep moving, as slow as ants in honey, tramping, treading ... Almost, as frightening were the white overseers who were patrolling the walkways - for not only were they coatless and hatless, with their sleeves rolled, but they were also armed with fearsome instruments: metal scoops, glass ladles and long-handed rakes." (Ghosh 2008, pp. 98-99)

The opium has the numbing effect of dulling all the senses of the coolies at work, be it visual, olfactory, aural, gustative or tactical. The opium factory though compared to a closed kitchen is filled 
with rancid odors that are in vivid contrast to the tasty spices and oil associated with gastronomical flavors and aromas in the cooking space. The putrid fumes from the opium tanks emit a stench that reeks of hard labor and ceaseless toil with workers wading waist-deep in opium tanks to brew the sap. Not only does the smoke hamper vision in the already dark and gloomy factory, but it also intoxicates the numerous laborers who trample on the opium sludgy paste to fashion it into the necessary consistence. Faceless men with no identities swirl the thick liquid with their bodies, while their drugged expressions speak volumes for their trance-like mechanical movements. Compared to insignificant and slow ants, they carry on the pain-staking activity under the watchful eyes of white supervisors who though devoid of hats and coats in the hot factory, however exhibit their superior status using "metal scoops" to inspect the liquid or "glass ladles" to push and entice the slave-like coolies into action or "long-handed rakes" that often dealt a blow to a child or laborer who lagged in his duty.

Ghosh's narrative set in the 1830s is historical with the destinies of the protagonists coinciding and interweaving within the context of the opium cultivation and production that financed the British Raj in India. Through a narrative configuring the opium trade and heterogeneous experiences, Ghosh weaves a common thread to link them together with their shared experiences as victimized natives during the materialistic colonial trade.

\section{Environmental Advocacy}

\subsection{Pining down the "Unknown" and Familiarizing the "Known"}

Ghosh's The Hungry Tide is set in the fickle tidal landscape or bhatir desh of the Sundarbans where the passage of the ebb tide leaves an ever-mutating and unpredictable terrain with "no borders to divide fresh water from salt, river from sea as " ... the water tears away entire promontories and peninsulas; at other times it throws up new shelves and sandbars where there were none before" (Ghosh 2004, p. 7). In this indeterminate fluid fictional space of the Sundarbans, narrated from an outsider's perspective, Ghosh takes the reader-voyager on a literary journey across the Gangetic delta that reveals the varied quests, travels, expeditions and voyages of the protagonists in the eco-narrative. The mighty River Hooghly dictates the literary journey in the novel as it meanders, changes course, reshapes land before sunrise and reconfigures them with new paths before sunset. During its ever-shifting course, the River Hooghly intertwines with the River Meghna, thus setting the theme of transformation for the human and animal inhabitants who adapt to the capricious river trajectories and deal with the challenging task of "naming" new, fresh, ever-emerging islands each day. The passage of tides and seasons prompt the Sundarbans Orcaella, the cetacean dolphin protagonists in the novel, to adapt their seasonal behavior to tidal ecology, fit them into the daily cycle of tides, swimming back and forth to the quiet Hooghly-Meghna river pools at day with the dawn ebb, and racing back to the stormy Bay of Bengal at night fall.

In The Hungry Tide, Ghosh speculates on the origin of the name of the mangrove forests, the "Sundarbans" and the anthropological, botanical, geo-tidal and historical influences in the bearing of its name.

"There is no prettiness here to invite the stranger in: yet, to the world at large this archipelago is known as "the Sundarban", which means, "the beautiful forest". There are some who believe the word to be derived from the name of a common species of mangrove- the sundari tree, Heriteria minor. But the word's origin is no easier to account for than is its present prevalence, for in the record books of the Mughal emperors this region is named not in reference to a tree but to a tide - bhati. And to the inhabitants of the islands this land is known as bhatir desh - the tide country-except that bhati is not just the "tide" but one tide in particular, the ebb-tide, the bhata: it is only in falling that the water gives birth to the forest. To look upon this strange parturition, midwived by the moon, is to know why the name "tide country" is not just right but necessary." (Ghosh 2004, pp. 98-99) 
"Naming" the tidal country as "beautiful" strikes the reader as both ironical and pertinent with the coincidental botanical and sematic reference to the sundari tree that bequeaths the name of the Sundarbans to the tidal mangrove forests in the Bengal basin. However, pinpointing the etymological route proves elusive in spite of Mughal attempts at documentation as tidal history of the web tide since "unrecorded" and "undocumented" time designates the ebb-tide as the force that sustains existence and rebirth in a world that depended on the waxing and the waning of the moon's lunar cycle. Like the sundari tree that lends its name to the Sundarbans, the garjon tree named and referred to in the novel, offers its botanical tag to the settlement of Garjontola, thus highlighting the fact that onomatopoeic references are often absent in the tidal country as the word signifying "garjon" or roar of a tiger's cry hold no meaning in the etymological lay of the fictional land. Ghosh also puts forward the idea that the re-naming of places is often confusing as in Kanai Dutt's occasional slip regarding the references to Calcutta as Kolkata. By sorting ideas and reserving the use of "Calcutta" for references to the past, and "Kolkata" for references to the present, the reader-voyager also does a simultaneous categorizing of references to the past and the present during the literary journey. Furthermore, the process of naming is a ritual in the fictional space to pin down the "unknown" and familiarize the "known".

“... she had been somewhat intrigued by this so far shown little interest in pointing to things and telling her their Bengal names. She had been somewhat intrigued by this for, in her experience, people almost automatically went through a ritual of naming when they were with a stranger of another language." (Ghosh 2004, p. 93)

To Piya, the American-born Indian cetologist, "naming" becomes a ritual of familiarization, though peculiarly transient and ephemeral in nature as in the tidal country, transitory land and scarce human belonging are subject to daily immersions and systematic re-naming. In The Hungry Tide, the processes of "naming" and "re-naming" are accompanied by a dual attempt to "classify", "categorize" and "label" cetacean aquatic life and different ecological niches of varying degrees of salinity and turbidity that had escaped the microscopic lens of avid botanists and zoologists the world over due to the nature of the dense, impenetrable forests. Piya's attempts to distinguish the patterns of behavior of the Orcaella brevirostris and its cousin, Orcaella fluminalis lead to a fascinating discovery of unknown local species from gargantuan crocodiles to microscopic fish existing in floating biodomes filled with endemic, rare and botanically unclassified flora and fauna in the marshy estuarine areas of the Sundarbans. While recording the teeming marine ecology, Piya highlights the eco-sensitive existence of micro-environments with their own patterns of life, floating midstream and wafting back to shore or retreating into deep islands only to re-emerge with new aquatic forms of life that baffled human attempts at scientific and systematic "naming" and "labelling". Piya's nomadic expedition highlights detailed water depth, underwater concavities, tides, currents of the so-far un-named Sundarbans aquatic ecology and focuses on how these variables speak for the dynamic, unstable interrelation between numerous "microenvironments" of floating biodomes of endemic aquatic life forms. Through the act of naming un-named species, Piya resists being categorized as a subaltern Indian or the lowest level of social hierarchy. In Spivak's article "Can the Subaltern Speak?", oppressed minorities characterized as Other are restricted by their linguistic competences, are denied the access to hegemonic power and do not have the opportunity of self-representation. Unlike Spivak's contention that "epistemic violence" obstructs, undermines non-Western methods or approaches to knowledge and that "... the subaltern has no history and cannot speak, the subaltern as female is even more deeply in shadow" (Morris and Spivak 2010, p. 28), Ghosh's eco-critical fiction lays stress on the interconnected nature of different life forms and Piya's quest to name un-named species can be considered as a creative endeavor to consider how these ecologically connected groups can be creatively transformed. Through the process of naming unidentified Western species, Piya resists the dominant Western narrative by creating a new form of representation. Ghosh's postcolonial narrative aims at showing how victims of colonial exploitation through their subaltern ways of resistance voice protest against the power imbalance between the colonist and the colonial subject, thus portraying a form of resistance described by Bill Ashcroft in Postcolonial Transformation where subaltern resistance could find an outlet as "any 
form of defense in which an invader is "kept out'" (as) "these subtle and more widespread forms of saying 'no' that are most interesting because they are most difficult for imperial powers to combat" (Ashcroft 2001, p. 20).

In an article written in 2004 entitled "Greening Postcolonialism: Eco-Critical Perspectives", Graham Huggan explains that in line with the growing concern for environmental and ecological problems on a global scale, it is inevitable that postcolonial literatures engage with these aspects of colonialism. He refers to the issues linked to "... the inseparability of current crises of ecological mismanagement from historical legacies of imperialistic and authoritarian abuse" (Huggan 2004, p. 702). Viewed in this light, Ghosh's fiction can be considered as a site where environmental and ecological issues are effectively problematized in relation to the hostile natural environment of the Sunderbans and the fragile ecological balance that must be maintained in a land of unpredictable ebb and flow tides. It is interesting to consider Huggan's views on the increasing traffic between eco-critical and postcolonial literary studies. He observes that the "green" turn in postcolonialism was a sign of the scholars' admission that it was impossible to analyze modern imperialism and colonialism without engaging with the massive scale of environmental devastation that they entail. It is thus evident that in Ghosh's fictional enterprise while configuring a postcolonial green, he lays stress on the interconnected nature of different life forms and Piya's quest to name un-named species can be considered as a creative endeavor to consider how these ecologically connected groups can be creatively transformed. In The Hungry Tide, Ghosh highlights how human lives are valued less than those of their tiger inhabitants in the Sunderbans. In the name of preservation, environmental injustice favors the existence of man-eating tigers, leaving humans at the mercy of governmental efforts to implement Project Tiger

“That tiger had killed two people, Piya,' Kanai said. 'And that was just in one village. It happens every week that people are killed by tigers. How about the horror of that? If there were killings on that scale anywhere else on the earth it would be called a genocide, and yet here it goes almost unremarked: these killings are never reported, never written about in the papers. And the reason is just that these people are too poor to matter. We all know it, but we choose not to see it. Isn't that a horror too-that we can feel the suffering of an animal, but not of human beings?" (Ghosh 2004, pp. 300-1)

The episode in the novel seeks to highlight the imbalance which exists between tigers that maul and consume helpless humans who are defenseless prey as they dare not retaliate. Governmental efforts to protect the tiger species result in large-scale killings that Kanai names as "genocide". Through metaphors of blindness to human suffering and the consequent numbing of senses and feeling, the incident in the novel shows how in the name of common good, governments have unthinkingly rendered the UNESCO heritage site of the Sundarbans, "inhabitable" for man, but "hospitable", "reserved" and "protected" for the tiger species. In this context, it should be remembered that the Sundarbans Tiger Reserve was created in 1973 to save the dwindling numbers of the fast-disappearing species and the reserve was declared a World Heritage site in 1997 to preserve the mangrove habitat and vegetation essential for its survival. However, efforts at ecological protection to save tigers and protect forests often disadvantage indigenous people who farm, forage, fish, subsist on nature, and struggle to preserve their village lifestyle from external intrusion. It is interesting to consider how international pressure on postcolonial states to conserve flora and fauna has resulted in a mutiny between ecologists who wish to prioritize the environment over all human needs, and social justice proponents who argue that human equity must precede green conservation and preservation. In the novel, Ghosh also seeks to show how governmental proposals to create an eco-tourist haven in the Sundarbans at the expense of rare species, is typical of the selfish human decision to survive at the expense of animal deterioration and " ... exploiting nature while minimizing non-human claims to a shared earth" (Huggan and Tiffin 2010, p. 5). 


\subsection{Articulating Resistance through an Eco-Narrative}

In the Ibis Trilogy, Ghosh's eco-narrative in the troubled waters of the South China Sea, the reader witnesses the tryst between two storm-tossed vessels: the Anahita, a sumptuously built cargo ship laden with opium and owned by the Bombay merchant Bahram Modi; and the Redruth, a two-masted vessel with a Cornish botanist searching for rare plants such as the golden camellia and Paulette his assistant who nurtures and takes cares of the flora during the stormy journey. In Sea of Poppies, the orphaned Paulette catalogued the Plants of Bengal and contributed to the body of collected knowledge called as the Materia Medica while in the sequel River of Smoke, Paulette, is discovered living in the ruins of a botanical garden by the famous plant hunter, Fitcher Penrose. They join forces to search for a species of rare camellia and seek newer vistas through botanical exploration. Penrose is portrayed as a plant hunter who had made a fortune through the marketing of seeds, saplings, plants, cutting and horticultural implements. His fortune earned through honest means was thanks to the sale of Chinese importations of plumbago, flowering quince and winter sweet. His visit to the Botanical Gardens of Pamplemousses in Port Louis traces the exploits of similar minded founders and curators in botanical history such as Pierre Poivre, who had identified the true black pepper or that of Philibert Commerson, the discoverer of bougainvillea. Ghosh details the route of pilgrimage undertaken by early horticulturists to the Pamplemousses garden in his eco-narrative. In Port Louis, Penrose discovers the existence of a chaotic botanical garden where a wild and tangled muddle of greenery showed the existence of a primeval jungle "where African creepers were at war with Chinese trees, nor one where Indian shrubs and Brazilian vines were locked in a mortal embrace. This was a work of Man, a botanical Babel" (Ghosh 2011, p. 39). The Redruth's clean, angular and curved lines seem built to weather the high storms and protect effectively the greenery on board. Even though plants bred for nutrition or decoration on sail ships were not an uncommon sight during that period, the Redruth stands apart from the rest with her stack of "Wardian cases" of "glass-fronted boxes with adjustable sides, they were, in effect, miniature greenhouses" (Ghosh 2011, p. 81). In the greenest section of the quarterdeck, the Redruth had movable awnings designed to provide shade and protection from sunlight and other inclement weather. Due to the presence of ever-thirsty flora on board, Fitcher had even devised a system of rain water collection to not let a single drop to go waste. The sailboat could also boast of unique procedures for dealing with waste as all refuse that could be used as plant nutrition was carefully separated from the remains of the salted meats and tea leaves, coffee grounds, rice, bits of old biscuit and hardtack were all stacked together and dumped into enormous barrels that were suspended over the stern. Each plant on board had been handpicked by Fitcher himself and varied from flora from the Americas to medicinal plants from the Far East.

“Nor was there anything at all haphazard about the Redruth's cargo. All her plants had been handpicked by Fitcher himself: most were from the Americas and had only recently been introduced to Europe and were thus unlikely yet to have reached China. Amongst this assemblage of flora were antirrhinums, lobelias and georginas, introduced from Mexico by Alexander von Humboldt; also from Mexico were the 'Mexican Orange' and a beautiful new fuchsia; from the American Northwest there was Gaultheria shallon, a plant both ornamental and medicinal, and a magnificent new conifer, both introduced by David Douglas-Fitcher was certain that the latter species would appeal especially to the pine loving Chinese. Shrubs were not neglected either: the flowering currant was a species for which Fitcher had very high hopes." (Ghosh 2011, p. 82)

It is interesting to note Fitcher's intention of exchanging these American plants for Chinese species that had not yet been introduced to the West. His ability to identify the rare flora of the mangrove forests is however linked to the materialistic intent of selling these plants for gain in richer pastures of the West. He even likens his botanical quest to that of the pursuits of D'Incarville, a Jesuit who had spent several years at the court of the Emperor, in Peking. Like the ingenuous priest who had conceived the idea of proposing a botanical exchange between the French King and his royal counterpart in 
China, thus bringing into the fictional space the journey made by tulips, cornflowers and columbines through the North China Sea to Europe. One named specimen in the novel of commercial value is Camellia sinensis, which gave camellia tea, and which accounted for " ... an enormous proportion of the world's trade and one-tenth of England's revenues" (Ghosh 2011, p. 107). Fitcher's careful collection of select varieties were based on what he considered as profitable and attractive to English gardeners such as "two varieties of wisteria, a seductive new lily, a fine azalea bush, an unusual primrose, a lustrous camellia and much else" (Ghosh 2011, p. 109). The Redruth bore the stamp as the "handiwork of a diligent nurseryman-not a man who was a speculative thinker, but rather a practical solver of problems, someone who looked upon Nature as an assortment of puzzles, many of which, if properly resolved, could provide rich sources of profit" (Ghosh 2011, p. 83). However, at the same time, though materialistic in trade, Fitcher is also portrayed as a man who had eked out his livelihood from flora but had little use for the material gain as "his wealth was a source not of comfort, but of anxiety-it was a burden, similar to the sacks of cabbages that had to be hoarded in the cellar for seasons of scarcity" (Ghosh 2011, p. 84).

On the contrary Paulette's identification of the shrubs and herbs by their botanical names seem only second nature to her. In the fictional space Paulette is the protagonist who voices the need to protect greenery and nature from forces that strive to destroy the landscape. As a child of nature, she had been taught by her father, Pierre Lambert to love nature and consider it as a kind of spiritual striving whereby the quest was to comprehend the inner vitality of each species.

If botany was the Scripture of this religion, then horticulture was its form of worship: tending a garden was, for Pierre Lambert, no mere matter of planting seeds and pruning branches-it was a spiritual discipline, a means of communicating with forms of life that were necessarily mute and could be understood only through a careful study of their own modes of expression - the languages of efflorescence, growth and decay: only thus he had taught Paulette, could human beings apprehend the vital energies that constitute the Spirit of the Earth. (Ghosh 2011, p. 83)

During the passage through the North China Sea, Paulette identifies a large variety of plants and tends them as would a priestess performing a spiritual ritual. Ghosh lays stress on the interconnected nature of different life forms and Paulette's quest to name un-named flora from Chinese territory that can be considered as a creative endeavor to consider how these ecologically connected groups can be creatively transformed. The ideology of resistance is thus exhibited through the spaces created by the subaltern characters in Sea of Poppies. The victims of colonial exploitation through their subaltern ways of resistance voice protest against the power imbalance between the colonist and the colonial subject. The mundane tasks of planting, pruning and watering become acts of discipline and a means of communication with mute forms of existence that manifest different kinds of vital energies that constitute the spirit of the Earth. She carefully observes the procedures and protocols on board during times of storms. As Fitcher's student she learns to identify the causes of wilting by tracing back the ills suffered by the plant to the composition of the earth in which it grew. By conjuring the right mix of "hot" and "cold" soils, she resuscitates wilting plants on the high seas. The sea with its vast quantities of seaweed also offer nature's cure to the rare plants on board when the botanists dried, ground and applied the mortar "in pinches, as though it were a rare remedy" (Ghosh 2011, p. 103). In the massive attempt to protect the rare flora, every piece of bone on board was boiled, powdered and transformed into manure rich in lime, magnesia and phosphates. At the same time, the eco-conservationists in the fictional space must deal with the discontent of the seamen on board who regarded the plants as threats to their existence and denied them water in times of scarcity or emptied the pots of precious water when menaced by storms. The reader encounters a multiplicity of voices that express the problems that the world faces today and discovers a plethora of issues that speak of the need to assert a "green" paradigm free of the stamp of lucrative colonial trade. 


\subsection{The Material Turn-Eco-Narrative versus Eco-Materialism}

This study draws inspiration from Benita Parry's Postcolonial Studies: A Materialistic Critique and aims at highlighting the violence and imbalance of colonial encounters. While Parry urges critics to orient their analysis towards a more materialistic critique that connects imperialism's epistemic violence and material aggression, my paper highlights an aspect that is missing in Parry's argument. Her contention of resistance theory is shaped from a meagre ideological perspective that leaves little room for smaller narratives of resistance. Throughout the work, Parry praises British Marxists' involvement in the liberation movements and passionately claims that Britain was the place where most of the anticolonial programs took off and where most of the native anti-colonialists had been trained. She thus tends to overlook the contribution of other parts of Europe and America, and she skims over the transnational dimension of anticolonial resistance. My study shows that by depicting the politics of resistance in colonial India in The Hungry Tide and the Ibis Trilogy through the lens of little narratives or stories of subalterns, Ghosh leads a materialist, historically circumstanced kind of enquiry. Through a portrayal of the British opium trade in China in the 1830s, Ghosh highlights the material impulses of colonials, the misappropriation of land and natural resources, and the transformation of the landscape from one yielding necessary crops to that of bonded labor producing opium to balance the West's trade with the East. The eco-narrative strives to remember the materialist past and the suffering of the subalterns, but at the same time aims at criticizing the contemporary political and economic situation in India, thus showing the "need to recall the long histories of injustice, to remember the obstacles in the way of building a just society and always to hold in view the prospect of a future. His eco-critical vision as shown in the Ibis Trilogy highlights the fact that " ... our best hope for universal emancipation lies in remaining unreconciled to the past and unconsoled by the present" (Parry 2005, p. 193). Through a material ecocritical approach, Ghosh examines "matter both in texts and as a text, trying to shed light on the way bodily natures and discursive forces express their interaction" (Iovino 2014, pp. 2). However, at the same time, he creates a fictional space whose history traces the opium trade, a story that is partly known and partly guessed. By configuring the British lucrative trade of opium on the Anahita and a simultaneous quest for protecting rare plants and sketches of these plants, Ghosh seeks to illuminate how displaced communities have to deal with hostile forces of natural environment and insensitive governments that ignore human attempts of survival in the name of protecting broader ecological concerns of the planet.

In River of Smoke, the ocean occupies center stage in the novel's deigesis. The ocean is the lieu of maritime trade affecting politics on land, agricultural production and environmental policy making. In the novel, the Indian Ocean welcomes sailors from India, China, Mauritius, Europe and the United States, but the trade is colonial with the terms being dictated by the British Empire. This archive of unfair trade still exists in today's world as seen in the IOR-ARC treaty signed by countries that share the Indian Ocean. Though created with the intention of being a platform for the peoples of the Indian Ocean Region to reconnect with each other, to discover their common heritage and deep-rooted affinities, to celebrate their shared cultural history and chart their own destinies, the free trade association has been criticized for having pitched too high or too low its tariffs and customs barriers. River of Smoke also reveals the loss of natural habitat and the destruction of the ecosystem during British colonial rule in the 19th century. The rivers in the fictional space bear witness to the destruction of native plants and the forced cultivation of opium poppies for lucrative gain. Interestingly, Fanqui town which in the fictional space is cast as the "threshold of the last and greatest of all the world's caravanserais" (Ghosh 2011, p. 197) resembles the contemporary setting in postcolonial countries that have to fight against the trade of illicit drugs. Ghosh's work is typical of postcolonial ecology where the literary form becomes a critical engagement with an aesthetics of the earth. Ghosh's literary enterprise with its hidden agenda of social and environmental advocacy is imaginative and serves as a catalyst for social action and exploratory literary analysis into a full-fledged form of engaged cultural critique. In today's postcolonial India, the cultivation of opium poppies is now regulated with farmers being constrained to produce only the required amount needed for medicinal or research purposes. However, 
the meagre remuneration offered to its cultivators, has resulted in drug smuggling turning into a lucrative trade. Thus, Ghosh also seeks to show how governmental proposals to create a drug free state at the expense of poor farmers, is typical of contemporary selfish political decisions to frame programs at the expense of the livelihood of poor farmers and exploiting nature while minimizing human claims to a shared earth. He criticizes the policies and government strategies of postcolonial governments where government policies take advantage of poor peasants in the name of common good by appropriating eco-friendly policy labelling.

Through a polyphony of voices of the subaltern in the novel, Ghosh gives precedence to the perspective of the colonized over that of the colonizer. In the Ibis Trilogy, the recurring line of thought highlights how "opium of course-is a monopoly of British government. Opium pays for everything-hotel, church, governor's mansion, all are built on opium" (Ghosh 2012). In this context, it is interesting to consider how the protagonists despite their diverse aims are brought together artificially by the opportunities for profit represented by the opium trade. In Sea of Poppies, Ghosh's storylines of the different protagonists reveal the varying intent behind the mass migration of these laborers and their quest for an uncertain dream of prosperity across the Black Water of the Indian Ocean. Due to its bad reputation as a slave-vessel, the Ibis is shunned by honest seamen, but attracts lascars on her desks who were sailors from disparate groups such as "Chinese and East Africans, Arabs and Malays, Bengalis and Goans, Tamils and Arkanese and had nothing in common except the Indian Ocean" (Ghosh 2008). With the new owner of Burnham Bros recruiting indentured labor for the trip's onward journey to Mauritius, the destinies of the protagonists coincide and interweave within this context of the opium trade that financed the British Raj in India. The British protagonists in the novel voice the imperial stance of waging the opium war by insisting on the fact that despite the British dislike for war, war was a necessary evil for the balance of trade between Britain and China. Mr Burnham declares, "No one dislikes war more than I do-indeed I abhor it. However, it cannot be denied that there are times when war is not merely just and necessary, but also humane. In China, that time has come: nothing else will do" (Ghosh 2008). With opium serving as the means of purchasing Chinese silk and tea, the British intent of declaring war for selfish means is cloaked by an announcement of war in the name of freedom.

"The war when it comes, will not be for opium. It will be for the principle: for freedom-for the freedom of trade and for the freedom of the Chinese people." (Ghosh 2008)

In the name of free trade, Burnham supports the British enterprise of waging war as agents in the pursuit of a higher good. Typical of the Orientalist quest of undertaking a "mission civilisatrice" and bringing the gifts of civilization to the so-called uncivilized East, the European position of bringing law and order or free trade or material progress is considered to be a Christian mission. The imperialistic stance of changing the very nature of free trade and taking complete control of opium trade due to its lucrative nature in the name of God further reiterates the British intent to eventually appropriate the monopoly of its cultivation in its colonies. Interestingly, the word "freedom" holds different significances for the protagonists. While Zachary associates freedom as a way of living one's life free from his former white masters, Burnham voices the feelings of British trade lords who consider freedom as a means of enhancing their lucrative business in colonies. Zachary's incredulity is evident as he is surprised by the fact that English laws do not outlaw the trade of slaves. In their mission to bring light to the uncivilized East, the British colonial endeavor lacks the "mission civilisatrice" of the Oriental quest. The reference to the African trade of slaves when triangular trade enabled the three-legged journey of exchanging slaves in Africa for guns and brandy, the Middle Passage across the Atlantic to sell the slaves in the West Indies and North America, and the final taking of cargo of rum and sugar to England. The ludicrous reference to a slave in the Carolina free from the autocratic rule of a dark tyrant highlights the British arrogance of assuming that opium could accomplish what sugar and alcohol did for the Americas and Africa.

The perceptive reader is aware that the mechanism of exploitation characteristic of colonial times exists even today in the form of economic, political and social imperialism. Ghosh's intent of 
highlighting the material forces and power relations at play in today's postcolonial context in India is a means of framing an eco-narrative or "greening postcolonialism" with its sub-stories of victims of colonial brutalities. In today's materialist world, he considers the need to recall the long histories of injustice, to remember the obstacles in the way of building a just society and always to hold in view the prospect of a future. He thus offers a new perspective of concerns and debates that affect the world at large, and the way these issues can be highlighted through eco-narrative versus eco-materialism, eco-critical activism for the preservation of life, environmental advocacy and aesthetics, and brings eco-criticism closer to the material turn by highlighting how narratives and stories contribute to making meaning of the material forces and substance that rule the world.

\section{Conclusions}

In his eco-critical writing, Ghosh delves into the challenges facing humanity in the era of the Anthropocene, the new geological period of time in which humans play a role in reshaping the planet and conserving it for future generations. He contends that humans as geological agents not only change the most basic physical processes of the Earth, but also that the "Anthropocene presents a challenge not only to the arts and the humanities, but also to our commonsense understandings and beyond that to contemporary culture in general" (Ghosh 2016). In trying to understand why contemporary culture finds it hard to deal with climate change, Ghosh posits that "the climate crisis is also a crisis of culture, and that of the imagination" (Ghosh 2016). He warns the present generation of authors that in an ever-changing world with sea level rising to swallow the Sundarbans and the increasing possibility of submerged cities such as Kolkata, New York, and Bangkok, it is time to find new forms of art and literature that reveal the plight at hand. Ghosh mines his own experience when he writes, linking together moments and scenes that are in some way distinctive or different: " ... these are, of course, nothing other than instances of exception ... It is through this mechanism that worlds are conjured up, through everyday details, which function 'as the opposite of narrative'" (Ghosh 2016). He contends that in the present era of "flash floods, hundred-year storms, persistent droughts, spells of unprecedented heat: sudden landslides, raging torrents pouring down from breached glacial lakes, and yes, freakish tornadoes, "we are confronted suddenly with a new task: that of finding other ways in which to imagine the unthinkable beings and events of this era" (Ghosh 2016). By configuring these natural phenomena in time and space of his novels, Ghosh creates texts that conjure up worlds that become real precisely because of their finitude and distinctiveness. Ghosh's literary enterprise with its hidden agenda of social and environmental advocacy is imaginative and serves as "a catalyst for social action and exploratory literary analysis into a full-fledged form of engaged cultural critique" (Huggan and Tiffin 2010). Through a fictional space whose history is partly known and partly guessed, a tide country that has constant accumulation of silt to cover its past, Ghosh seeks to illuminate how displaced communities must deal with hostile forces of natural environment and insensitive governments that ignore human attempts of survival in the name of protecting broader ecological concerns of the planet. Through the representation of the Sundarbans as an eco-sensitive region, he brings forth the idea that it is difficult to address the ecological concerns of the planet without a close appraisal of the human and cultural issues entwined with natural ecosystems. Similarly, in the Ibis Trilogy, the reader encounters a multiplicity of voices that express the problems that the world faces today and discovers a plethora of issues that speak of the need to assert a "green" paradigm free of social and racial injustices. This attempt to unite fictional aesthetics and advocacy is typical of postcolonial eco-criticism that seeks to advocate social and environmental justice in today's postcolonial world. The fictional enterprise of underlining the need for social and political change speaks of Ghosh's envisioning of a "postcolonial green" that campaigns for the transference from "red" to "green" politics and the need to dwell as responsible inhabitants who believe in global justice and sustainability on our planet. 
Funding: This research received no external funding.

Conflicts of Interest: The author declares no conflict of interest.

\section{References}

Ashcroft, Bill, Gareth Griffiths, and Helen Tiffin. 2002. The Empire Writes Back: Theory and Practice in Post-Colonial Literatures, 2nd ed. New York: Routledge, p. 196. ISBN 978-0415280204.

Ashcroft, Bill. 2001. Post-Colonial Transformation. London: Routledge, pp. 20-21. ISBN 978-0415238304.

Chouvy, Pierre-Arnaud. 2010. Uncovering the Politics of the Poppy. Cambridge: Harvard University Press, pp. 1-5. ISBN 978-0674051348.

Ghosh, Amitav. 2008. Sea of Poppies. London: John Murray, pp. 396-97. ISBN 978-0719568978.

Ghosh, Amitav. 2011. River of Smoke. London: John Murray, pp. 39-197. ISBN 978-1250013750.

Ghosh, Amitav. 2012. Flood of Fire. London: John Murray, pp. 14-120. ISBN 978-1473626850.

Ghosh, Amitav. 2016. The Great Derangement: Climate Change and the Unthinkable. London: University of Chicago Press, pp. 1-33. ISBN 9780226526812.

Ghosh, Amitav. 2004. The Hungry Tide. New Delhi: Ravi Dayal, pp. 7-93. ISBN 978-0618711666.

Huggan, Graham, and Helen Tiffin. 2010. Postcolonial Ecocriticism: Literature, Animals Environment. London: Routledge, pp. 1-23. ISBN 978-0415344586.

Huggan, Graham. 2004. 'Greening' Postcolonialism: Ecocritical Perspectives. Modern Fiction Studies 50: 701-33. [CrossRef]

Iovino, Serenella. 2014. Material Ecocriticism. Bloomington: Indiana University Press, pp. 1-2. ISBN 978-0253013989. Morris, Rosalind C., and Gayatri C. Spivak. 2010. 'Can the Subaltern Speak?' Reflections on the History of an Idea. New York: Columbia University Press, pp. 21-78. ISBN 978-0231143851.

Parry, Benita. 2005. Postcolonial Studies: A Materialist Critique. New York: Routledge, pp. 193-94. ISBN 978-0415335997. Said, Edward. 1998. Orientalism. Literary Theory: An Anthology. Cornwall: Blackwell, pp. 31-62. ISBN 978-0394740676. Trocki, Carl A. 1999. Opium, Empire and the Global Political Economy. London: Routledge, pp. 7-8. ISBN 978-0415215008.

(C) 2018 by the author. Licensee MDPI, Basel, Switzerland. This article is an open access article distributed under the terms and conditions of the Creative Commons Attribution (CC BY) license (http:/ / creativecommons.org/licenses/by/4.0/). 